\title{
Applicability of 3D laser scanning in precision horticulture
}

\author{
Tamás, J. ${ }^{1}$, Riczu, P. ${ }^{1}$, Nagy, G. ${ }^{2}$, Nagy, A. ${ }^{1}$, Jancsó, T. ${ }^{2}$, Nyéki, J. ${ }^{3}$ \& Szabó, Z. ${ }^{3}$ \\ ${ }^{1}$ University of Debrecen, Institute of Water and Environmental Management, \\ Debrecen, 4032.Böszörményi str.138.tamas@agr.unideb.hu \\ ${ }^{2}$ University of West-Hungary, Faculty of Geoinformatics, Department of Geoinformation Science, \\ Székesfehérvár, 8000. Pirosalma str. 1-3. \\ ${ }^{3}$ University of Debrecen, Institute for Research and Development, Debrecen, 4032. Böszörményi str. 138.
}

\begin{abstract}
Summary: Due to the technological development, remote sensing instruments and methods have become widespread in all segments of life (from precision agriculture through architecture to medicine). Among the innovative development of remote sensing instruments the 3D laser scanner is of outstanding importance. Horticultural applicability of terrestrial laser scanning technique is a new innovation in the precision agriculture. The structure of trees and branches, the canopy extension, the fruit yield, which can help to recognize some biophysical parameters, can be determined. The examination was carried out with Leica ScanStation C10 terrestrial laser scanner in the Study and Regional Research Farm of the University of Debrecen near Pallag. In this article the measuring principle, the parameters and horticulture applicability of the terrestrial laser scanner are presented.
\end{abstract}

Key words: laser scanning, LIDAR, precision horticulture, 3D modeling, apple

\section{Introduction}

The production of marketable horticulture products is difficult without quality horticulture practice, which in many cases is primary condition of appropriate management system. The precision agriculture and precision horticulture contribute to the high quality yield production. Besides the environmental and field protection, the costs reductions, increases of efficiency are justified the widespread of precision techniques. Presently, the development of fast information technology gives our hand such methods like global positioning system (GPS), Geographic Information System (GIS), remote sensing (RS). Covered and uncovered ground can be quickly, accurately and cost effectively examined on large area (Burai, 2007). This ternary technology apace develop an integrated complementary in geospatial sciences and researches.

Remote sensing (RS) is rapidly developing discipline. Remote sensing, also called earth observation, refers to obtaining information about objects or areas at the Earth's surface without being in direct physical contact with the object or area (Belényesi et al., 2008). According to Lóki (1996) the remote sensing means not only a special data collection, but processing and evaluation of these data also. Remote sensing provides to get information from large areas beside/instead of traditional sampling data (Burai, 2007).

The principle of remote sensing based on interactions and investigations of electromagnetic radiation with material (e.g. earth's surface). These thoughts were formulated in the early 1930s by Krinov Soviet scientist. The basis of remote sensing is incoming radiation to the object $\left(\mathrm{E}_{\mathrm{I}}\right)$. When the radiation incident upon the object's surface, is either reflected $\left(\mathrm{E}_{\mathrm{R}}\right)$ by the surface, transmitted $\left(\mathrm{E}_{\mathrm{T}}\right)$ into the surface or absorbed $\left(\mathrm{E}_{\mathrm{A}}\right)$ and emitted by the surface. These variables are depending by the wavelength $(\lambda)$. So, it could be created the following equation:

$$
\left(\mathrm{E}_{\mathrm{R}}\right)(\lambda)+\left(\mathrm{E}_{\mathrm{A}}\right)(\lambda)+\left(\mathrm{E}_{\mathrm{T}}\right)(\lambda)=\left(\mathrm{E}_{\mathrm{I}}\right)(\lambda)
$$

It could be determined from the equation that on given wavelength the reflection, absorption and transmission are equal to the total incoming radiation. The values are always depended on the physical characteristics of the object and the geometric structure (Molenaar, 1993). When a remote sensing instrument has a line-of-sight with an object that is reflecting solar energy, then the instrument collects that reflected energy and records the observation. Most remote sensing systems are designed to collect reflected $\left(E_{R}\right)$ radiation (Short, 2011). Based on the measured values it could be concluded to physical and possibly chemical characteristic of the observed object (Molenaar, 1993).

There are two types of remote sensing: passive remote sensing and active remote sensing. Passive remote sensing is detected natural radiation that is reflected by the object or surrounding area being observed. Reflected sunlight is the most common source of radiation measured by passive sensors (Belényesi et al., 2008). The active sensors emit a 


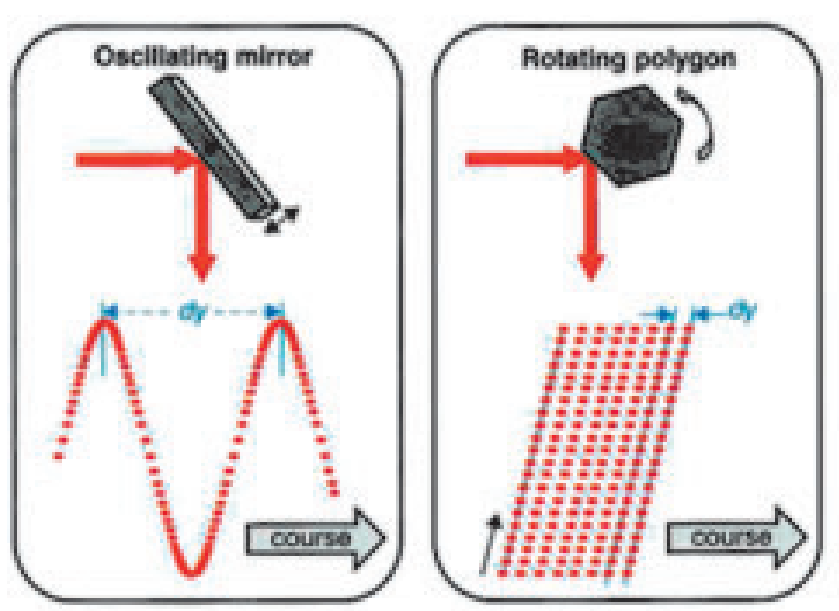

Figure 1 Scanning mechanisms and resulting ground patterns Source: Vosselman and Hans-Gerd 2010

certain radiation. It could be measured the reflected part of this emitted energy from the object. Active remote sensing systems are available in all weather conditions, day or night. The principle of active remote sensing is already used in World War II. for RADAR (RAdio Detection And Ranging) detection. Radar works by sending out radio signals in microwave range, and then waiting for them to bounce off the ground and return. The reflected radar signals are sensed by the detector. By measuring the amount of time it takes for the signals to return. Another type of remote sensing technique is laser scanning (LIDAR - LIght Detection And Ranging). The LIDAR are similar to RADAR systems, but in this case a laser light sweeps the object or the earth's surface (Belényesi et al., 2008). The laser scanner analyzes a real-world or object environment to collect data on its shape and possibly its appearance (e.g. color). The collected data can then be used to construct digital, two-dimensional drawings or threedimensional models useful for a wide variety of applications. The advantage of laser scanning is the fact that it can record huge numbers of points with high accuracy in a relatively short period of time (Lerma García et al., 2008). The 3D model building is occurred, if it is known the distances (so positions) of the measured points to the laser scanner. Determination of one point's distance could be occurred based on 3 methods:

1. The mathematical basis of the triangle (trigonometry), which is at the basis of these triangulation based measurement techniques. A triangulation laser scanner uses the same principle to probe the environment. It shines a laser pattern onto the subject and exploits a camera to look for the location of the laser's projection on the object. The laser emitter and the camera are setup under a constant angle, creating a triangle between them and the laser projection on the object, hence the name triangulation. Because of this configuration, the laser projection changes in the camera's field of view depending on the distance to the camera. This method is applied in short range and high precision laser scanners.

2. The light waves travel with a finite and constant velocity
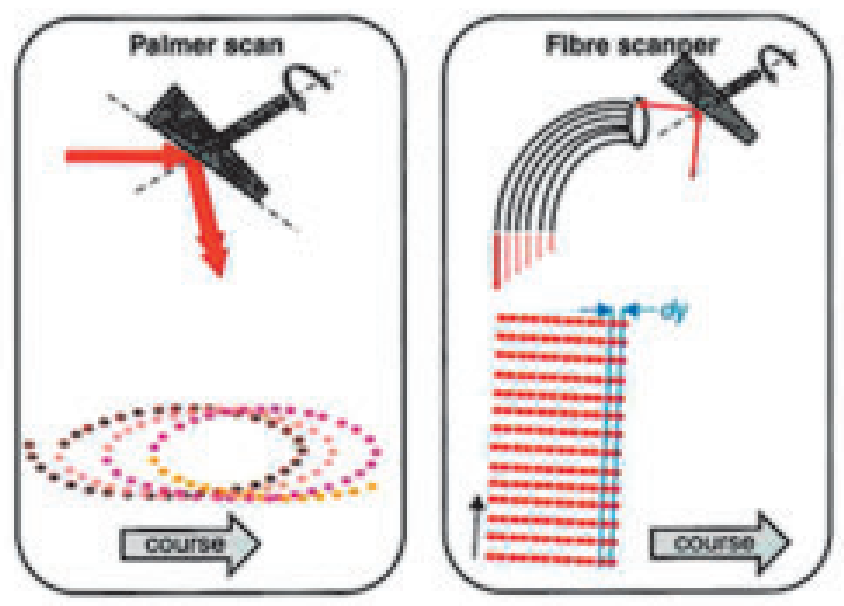

in a certain medium. Therefore, when the time delay created by light travelling from a source to a reflective target surface and back to the source (round trip) can be measured, the distance to that surface can be evaluated. The measurement of these laser scanners are based on time-of-flight (TOF) method

3. The emitted (incoherent) light is modulated in amplitude and fired onto a surface. The scattered reflection is collected and a circuit measures the phase difference between the sent and received waveforms, hence a time delay. Typical phase-based scanners modulate their signal using sinusoidal modulation, amplitude based (AM) or frequency based (FM) modulation, pseudo-noise or polarization modulation (Lerma García et al., 2008; Vosselman and Hans-Gerd, 2010).

To be able to measure multiple points from the same scanner point of view, the laser beam needs to be deflected. Instead of moving the laser itself, a deflection unit is used (Figure 1.). Most deflection units make use of a mirror because they are much lighter and can thus be rotated much faster and with greater accuracy. A number of methods exist to deflect the laser beam towards a specific direction without having to move the scanner itself (Lerma García et al., 2008).

To the 3D modeling of a certain surface is necessary more scan stations sweep the object, so it could be get a point cloud, which is contain more million points. The instrument is put the scan stations in a common coordinate system, so it is create the spatial location of the target.

Airborne laser scanning has already been adopted and accepted as a very valuable tool in forestry applications shortly after its advent as a commercially available measurement technique in the 1990s. The using of terrestrial laser scanner (and mainly airborne laser scanning technology) has been even less spread in horticulture applications (Vosselman and Hans-Gerd, 2010). Both in two areas (forestry and horticultural applications) with laser scanner technology it could be recognized the structure of trees, the canopy extension and else structural aspects, so it could be long term shadowing many biophysical processes and monitored the changes (Rosell et al., 2009). So it could be recognized photosynthesis, 
growth, $\mathrm{CO}_{2}$-sequestration and evapotranspiration ( $\mathrm{Li}$ et al., 2002; Rosell et al., 2009).

\section{Materials and methods}

The laser scanning was carried out in Study and Regional Research Farm of the University of Debrecen near Pallag. The study area was an intensive apple orchard with drip irrigation system, protected by hail net. The ScanStation C10 by Leica Geosystems uses the time-of-flight (TOF) principle for ranging. A short laser pulse is emitted towards the object and is reflected on its surface; a part of the reflected radiation comes back to the scanner where it is detected by a sensor.

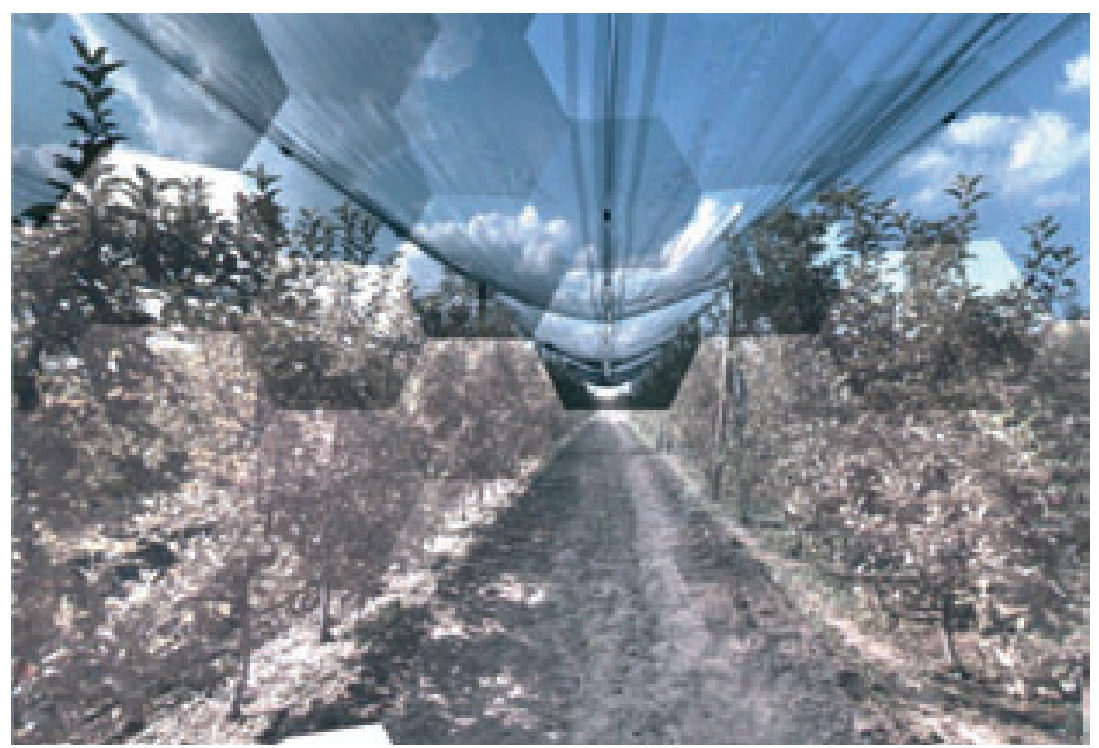

Figure 2. Digital image mosaic of the first scan station under hail protection net

The fast determination of objects is provided by a high scan rate of up to 50,000 points/sec. The emitted laser beam is $532 \mathrm{~nm}$ wavelength, so the color is green. The green laser light sweeps the objects; the deflection of laser beam is occurred by a Smart X-Mirror ${ }^{\mathrm{TM}}$ automatically spins polygon mirror system. Thus the scanner creates with high speed a point cloud. The maximum range of laser scanner is $300 \mathrm{~m}$; it is depend on the albedo. The coherence of laser beam is high, but if increase the range - increase the beam divergence too - so the scanning error is more and more bigger. Because of the larger beam diameter is more probability that the laser beam hits an edge on the object, so the beam is split in two parts. The result of this mixed edge problem is inaccuracy of distance. This error is bigger in case of vegetation scanning, because the plants have less plain parts, like e.g. buildings. The beam divergence is $0.1 \mathrm{mrad}$; it means that the diameter of laser point is $10 \mathrm{~mm}$ on $100 \mathrm{~m}$. This value is - in case of maximal measurement distance (on $300 \mathrm{~m}$ ) - only $3 \mathrm{~cm}$. The Field-of-View (horizontal $360^{\circ}$ and vertical $270^{\circ}$ ) is arisen from the construction of instrument, since the laser scanner doesn't survey under itself in $90^{\circ}$.
Near the laser emitter it could be found an auto-adjusting, high-resolution digital camera with zoom video. The integrated 4 megapixel (1920x1920 pixel) camera takes photos to color the point cloud. The Field-of-View of the camera is $17^{\circ}$, so the automatically spatially rectified (panoramic) dome was made form 260 images on each scan position (Figure 2).

We have surveyed one row of study area with 7 scan stations. There were 3 scan positions (distances are about $14 \mathrm{~m}$ ) on the left side and 4 scan positions (distances are about $24 \mathrm{~m}$ ) on the right side. The overlapping of scanning areas provided the unifying of point cloud, and increased the accuracy of measurement. The scan resolution was $8 \mathrm{~mm}$ on $10 \mathrm{~m}$; it means that the accuracy was below $1 \mathrm{~cm}$ on the right side.

The processing of raw point cloud was carried out by Leica Cyclone 7.1 and 3DReshaper software. The two softwares are appropriate for cleaning the point cloud form noises, and ideal for several engineering calculations.

\section{Results and discussion}

The laser scanning was carried out in Study and Regional Research Farm of the University of Debrecen near Pallag. The colors of point cloud indicated different intensity values. After cleaning the point cloud, a tree was chosen for the examination. The software could be fitted an object depending on the topology of the scanned point clouds. We have modeled the stem of investigated tree, and Cyclone fitted the best shape which was a cylinder. Then we were able to determine some characteristics of this cylinder, such as (stem) diameter, height, surface and volume calculation too (Figure 3).

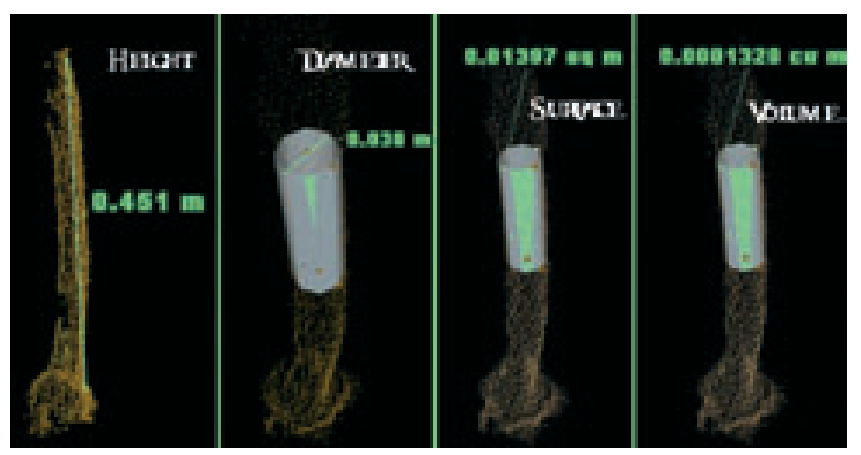

Figure 3. Model of a chosen apple tree's stem and the counting parameters

Some trees on the study area had not been harvested yet, so the instrument scanned the fruits too. We have built the apples in 3DReshaper (Figure 4.). The point cloud from the apples weren't full, but the 3DReshaper fitted a sphere, based on the curvature of point cloud. 


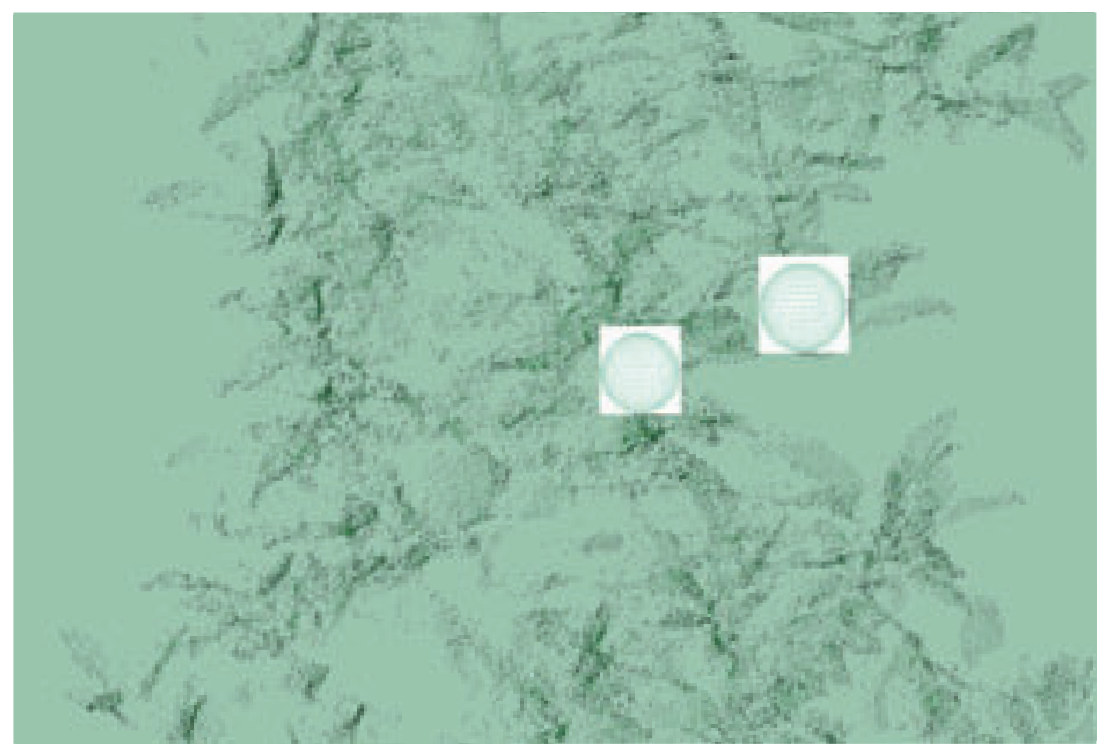

Figure 4. The built apple fruit model in 3DReshaper based on curvature of point cloud

Attila Váradi from Leica Geosystems Hungary Ltd. for his assistance in Leica software processing. The author would also like to thank Prof. József Nyéki for his scientific advice in many aspects of the experimental work. This study is funded by TECH_08-A3/2-2008-0373 and TECH_08A4/2-2008-0138 projects.

\section{References}

Belényesi, M., Kristóf, D. \& Skutai, J. (2008): Távérzékelés a környezetgazdálkodásban. Elméleti jegyzet. Szent István Egyetem, Környezetgazdálkodási Intézet, Gödöllő, p. 78.

Burai, P. (2007): Távérzékelési módszerek összehasonlító elemzése mezőgazdasági területeken. Doktori $(\mathrm{PhD})$ értekezés. Debrecen.

Lerma García, J. L., Van Genechten, B., Heine, E. \& Santana Quintero, M. (2008): Theory and

\section{Conclusion}

The laser scanning technology provides such a database, which can determine some characteristics of investigated trees with fast, non-destructive method. Nevertheless, based on the fitted sphere of curvature apple's point cloud the weight of apple fruit can be determined, so it is possible to predict the total yield of an orchard. In the future we would like to identify the length and angles of branches, the full 3D structure and the growing mechanisms of trees. These parameters could help in some precision horticulture applications. The geometry of trees and the canopy structure influence the incoming among of sun to the center of trees. Thus, optimal canopy and crown structure contribute to more yield. Further studies are also necessary to estimate the leaf area with laser scanning technology, since the dynamic of transpiration can be determined. Using these measurements water use efficiency of trees can be estimated. Based on the results, it could be possible to develop a water and energy saving irrigation system. This system can also be supplied by other remote sensing (e.g. hyperspectral) applications, which results more precise water use in orchards (Nagy et al. 2009).

\section{Acknowledgment}

The laser scanning was provided by the University of West-Hungary, Faculty of Geoinformatics. The authors thank practice on Terrestrial Laser Scanning. pp. 261; Editorial de la Universidad Politécnica de Valencia., Valencia, SPAIN.

Li, F., Cohen, S., Naor, A., Shaozong, K. \& Erez, A. (2002): Studies of canopy structure and water use of apple trees on three rootstocks. Agricultural Water Management 55: 1-14.

Lóki, J. (1996): Távérzékelés. Kossuth Egyetemi Kiadó. Debrecen, p. 113.

Molenaar, M. (1993): Remote Sensing as an Earth Viewing system. [In: Buiten, H. J. - Clevers, J. G. P. W. (szerk.): Land Observation by Remote Sensing - Theory and Applications.] Overseas Publishers Association, Amsterdam. p. 27-36.

Nagy, A., Tamás, J. \& Nagy, I. (2009): Őszibarack ültetvény lombozatának vizsgálata hiperspektrális adatok alapján [In: Tóth G. (ed.) LI. Georgikon Napok Tudományos Konferencia], Keszthely, 643-652.

Rosell, J. R., Llorens, J., Sanz, R., Arno, J., Ribes-Dasi, M., Masip, J., Escola, A., Camp, F., Solanelles, F., Gracia, F., Gil, E. \& Val, L. (2009): Obtaining the three-dimensional structure of tree orchards from remote $2 \mathrm{~d}$ terrestrial LIDAR scanning. Agricultural and Forest Meteorology 149: 1505-1515.

Short, N., M. (2011): The Remote Sensing Tutorial. online: NASA. (http://rst.gsfc.nasa.gov/Front/overview.html/)

Vosselman G., Hans-Gerd M. (2010): Airborne and Terrestrial Laser Scanning. Whittles Publishing, CRC Press. 336 p. 